\title{
Recurrent schwannoma of the tongue in a pediatric patient-report of a rare case with an updated review of literature
}

\author{
Anup Singh*iD, Vaisakh Kuzhikkali and Arvind Kumar Kairo
}

\begin{abstract}
Background: Head and neck is a relatively common site of occurrence for the peripheral nerve sheath tumors, and majority of these tumors are seen involving neck, involving vagus nerve, and cervical sympathetic chain.

Schwannomas involving mobile tongue are rarely encountered, especially in the pediatric population

Case presentation: We present a case of recurrent tongue schwannoma in a 13-year-old female successfully managed with transoral excision. At a follow-up of 3 years, no recurrence is observed.

Conclusion: Surgical excision is the recommended modality of treatment for lingual schwannomas, and when excised adequately, recurrences are not expected. A clear margin of surrounding normal tissue should be aimed for to avoid possible recurrence.
\end{abstract}

Keywords: Tongue, Child, Schwann cell, Schwannoma, Soft tissue neoplasms, Recurrence

\section{Background}

Schwannomas are benign tumors arising from the nerve sheath cells (Schwann cells), cranial nerves/autonomic nerves, and peripheral motor-sensory nerves. Head and neck involvement is common, constituting 25-45\% of all the cases and the commonest site of involvement in head and neck is cerebello-pontine angle/8th nerve complex [1]. Of the extracranial/non-vestibular cases, the commonest location is parapharyngeal space (vagus nerve and cervical sympathetic trunk). Oral cavity schwannomas constitute only $\sim 1 \%$ of head and neck schwannomas and as such are quite low down in the list of differential diagnosis of oral tumors. The age group usually affected with pathology is 3rd to 6th decade [2]. We discuss a pediatric patient with recurrent schwannoma of tongue managed with surgical excision and review pertinent literature regarding the schwannomas of tongue in the pediatric population.

\footnotetext{
*Correspondence: anoop.aiims1@gmail.com

Department of Otolaryngology and Head \& Neck Surgery, All India Institute of Medical Sciences, New Delhi 110029, India
}

\section{Case presentation}

A 13-year-old female patient presented to us with a 6month history of gradually enlarging mass lesion involving tongue. The patient did not report pain, bleeding, chewing difficulty, dysphagia, breathing difficulty, snoring, neck swelling, or any systemic symptoms. The patient had a history of excisional biopsy under general anesthesia for swelling at the same site 3 years back at another center and the post-operative histopathology was suggestive of benign nerve sheath tumor (schwannoma). On examination, the lesion was ovoid, smooth surfaced, mucosa covered, yellowish-pink, $\sim 2-1.5 \mathrm{~cm}$ in size, non-tender, firm with a broad base located at the junction of anterior two-third and posterior one-third of the left side of the tongue (Fig. 1a). Tongue mobility was normal. The rest of the systemic examination did not reveal any abnormality. With a possibility of a recurrent lesion, a contrast-enhanced MRI was obtained, which showed a $1.6 \mathrm{~mm} \times 1.4 \mathrm{~mm} \times 1.4 \mathrm{~mm}$ wellcircumscribed lesion, hypointense on T1, homogenously hyperintense on T2, and with avid homogenous enhancement on contrast administration (Fig. 2). A wedge

\section{Springer Open}

(- The Author(s). 2021 Open Access This article is licensed under a Creative Commons Attribution 4.0 International License, which permits use, sharing, adaptation, distribution and reproduction in any medium or format, as long as you give appropriate credit to the original author(s) and the source, provide a link to the Creative Commons licence, and indicate if changes were made. The images or other third party material in this article are included in the article's Creative Commons licence, unless indicated otherwise in a credit line to the material. If material is not included in the article's Creative Commons licence and your intended use is not permitted by statutory regulation or exceeds the permitted use, you will need to obtain permission directly from the copyright holder. To view a copy of this licence, visit http://creativecommons.org/licenses/by/4.0/. 


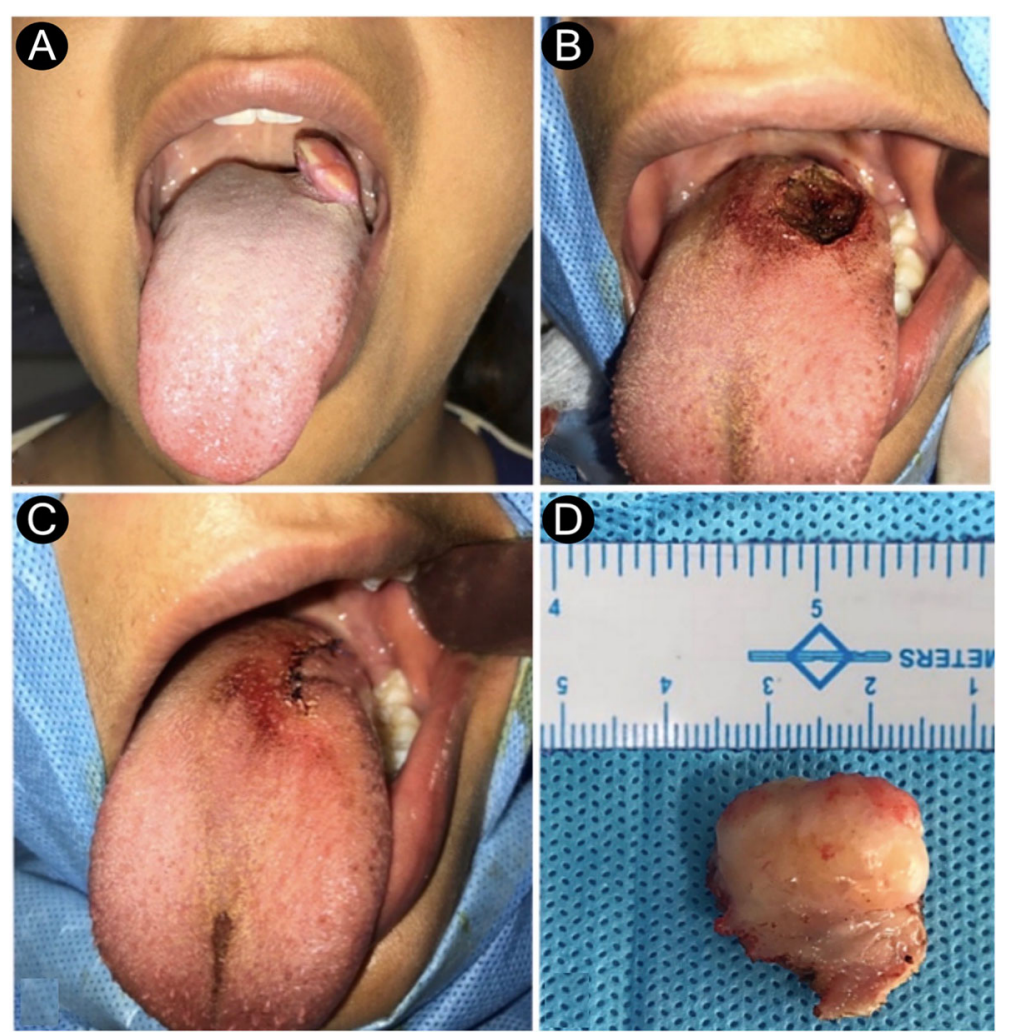

Fig. 1 a Showing the tumor involving the left posterior tongue with a wide base. $\mathbf{b}$ Intraoperative picture of the wound bed after complete excision. c Wound closed primarily, and $\mathbf{d}$ The specimen after complete excision with adequate margins

biopsy taken under local anesthesia from the lesion showed features suggestive of benign nerve sheath tumor. The patient and the relatives were explained about the need for surgical intervention and opted for the excision of the tumor under sedation (ketamine 1 $\mathrm{mg} / \mathrm{kg}$ along with intravenous ondansetron $4 \mathrm{mg}$ stat dose). With a good mouth opening and mobile tongue, the tumor could be adequately exposed transorally and wide excision with a cuff of surrounding soft tissue ( $0.5-1 \mathrm{~cm}$ ) was carried out (Fig. 1b, d). The nerve of origin was not discernible intraoperatively. The defect was primarily closed (Fig. 1c) and the post-operative period was uneventful. Post-op histopathology confirmed the diagnosis of schwannoma (Fig. 3) with clear margins. The post-operative period was uneventful. During a follow-up of 3 years, the surgical site is well healed without any evidence of recurrence.

\section{Discussion}

Intraoral schwannomas tend to involve the tongue followed by the floor of mouth, palate, buccal mucosa, gingiva, lip, and vestibule [3]. Involvement of tongue in the pediatric age group is a rare occurrence. A PubMed
English language literature review of lingual schwannomas in pediatric patients, dated 28th February 2021, including the case reports and series with clearly defined individual patient characteristics revealed a total of 34 cases of patients in age group $\leq 18$ years (Table 1) [316]. The first documented case of pediatric lingual schwannoma was by Craig [4] in 1964 in an 8-year-old female patient. The youngest patients (7 years old) were reported by Cinar [9] in 2004 and Enoz [10] in 2006 and recently by Thompson et al. [16]. There were 16 male and 18 female patients. The most common symptom, present in nearly three-fourth of the patients, was a painless lump. Other symptoms at the time of presentation included paresthesia, ulceration, bleed, and mechanical obstructive symptoms in the form of snoring, difficulty in mastication, swallowing, breathing, and phonation in varying combinations. The average size at the time of presentation was $19.6 \mathrm{~mm}$ (standard deviation: 10.5; range 5 to $50 \mathrm{~mm}$ ) and the tumor was present in anterior/ anterolateral part of the tongue in $58.8 \%$ of the cases. An uneventful and complete excision of the tumor could be carried out in all the patients transorally without resorting to more invasive and 


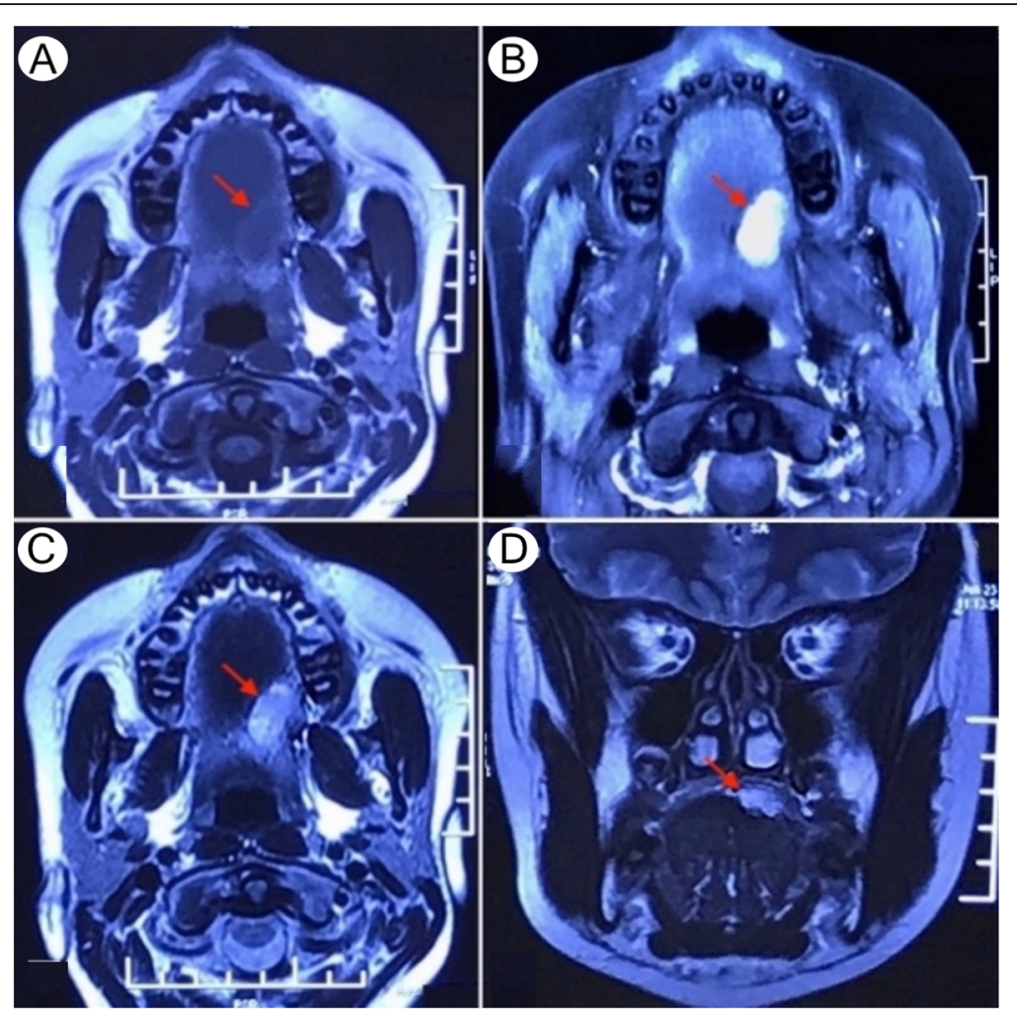

Fig. 2 CE-MRI face (coronal cuts a-c axial cuts d) showing the tumor involving left side posterior tongue (red arrow). a The tumor is isointense on $\mathrm{T} 1, \mathbf{b}$ brightly and uniformly enhancing on contrast administration, and $\mathbf{c}$ heterogeneously hyperintense on $\mathrm{T} 2$

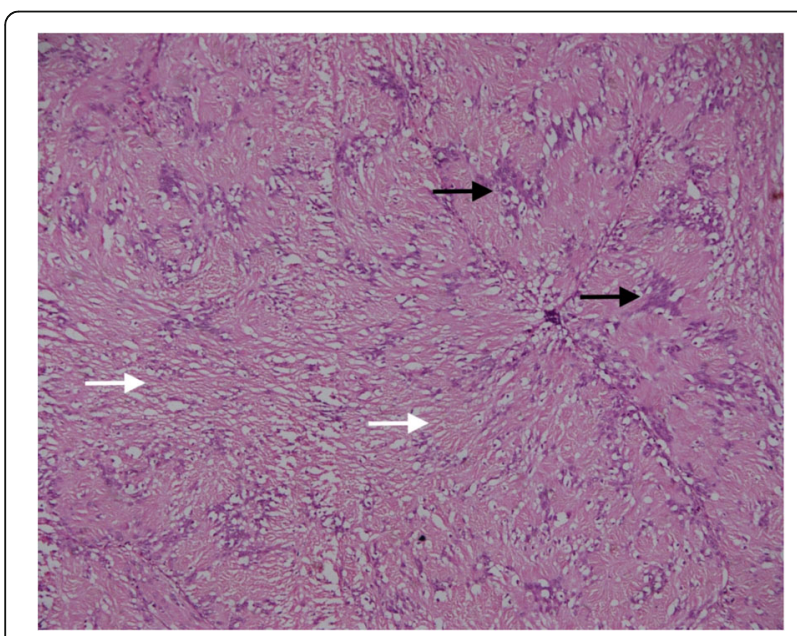

Fig. 3 Post-operative histopathology showing 'Antony A' (black arrows) and 'Antony B' (white arrows) areas characteristic of Schwannoma. (hematoxylin and eosin stain; original magnification $\times 10)$ morbid approaches. Follow-up was available in $70.6 \%$ of the cases, with a median duration of follow-up being 13.5 months (range 1 to 136 months), without any reported recurrences.

It is interesting to note that despite having nerve sheath origin, these tumors are seldom painful. In tongue, these tumors may arise from hypoglossal, lingual, or glossopharyngeal nerve but the nerve of involvement may be difficult to discern. It is easy to misinterpret these tumors with other soft tissue tumors like granular cell tumors, neurofibromas, mucoceles, salivary gland tumors, and leiomyomas on the basis of clinical appearance.

The gold standard of diagnosis remains histopathology. The light microscopic findings are distinctive enough to confer a diagnosis of schwannoma. If needed, the diagnosis can be reinforced with immunohistochemical staining with S-100 protein, which is seen to be present diffusely and uniformly in the tumor tissue [12].

Surgical excision remains the treatment of choice given the radioresistant nature of these tumors and relatively straightforward transoral access in cases of tumors involving the mobile tongue. In the current review, all the tongue tumors could be accessed 
Table 1 Pediatric lingual schwannomas-review of literature

\begin{tabular}{|c|c|c|c|c|c|c|c|c|c|}
\hline $\begin{array}{l}\text { SN } \\
\text { [ref] }\end{array}$ & Author & Year & Age (years) & Sex & Symptom & $\operatorname{Size}^{\mathrm{a}}(\mathrm{mm})$ & Site & $\begin{array}{l}\text { Surgical } \\
\text { approach }\end{array}$ & $\begin{array}{l}\text { FU } \\
\text { (months) }\end{array}$ \\
\hline $1[4]$ & Craig & 1964 & 8 & $\mathrm{~F}$ & Painless mass & 30 & Posterior & Transoral & NA \\
\hline $2[5]$ & Uj & 1967 & 13 & $\mathrm{~F}$ & Painless mass & NA & NA & Transoral & NA \\
\hline $3[6]$ & Barbosa et al. & 1984 & 12 & M & Painless mass & 5 & NA & Transoral & NA \\
\hline $4[7]^{b}$ & Piatelli et al. & 1984 & 18 & $\mathrm{~F}$ & Painless mass & NA & Anterior & Transoral & NA \\
\hline $5[8]$ & Akimoto et al. & 1987 & 14 & M & Painless mass & 10 & Anterior & Transoral & NA \\
\hline $6[8]$ & Siar et al. & 1988 & 17 & $\mathrm{~F}$ & Painless mass & 30 & Posterior & Transoral & 12 \\
\hline $7[8]$ & Siar et al. & 1988 & 13 & $\mathrm{~F}$ & Painless mass & 44 & NA & Transoral & 8 \\
\hline 8 [3] & Pfeifle et al. & 2001 & 18 & M & Painless mass & 20 & Anterior & Transoral & NA \\
\hline $9[8]$ & Bassichis et al. & 2004 & 9 & M & Snoring, breathing difficulty & 23 & Posterior & Transoral & 60 \\
\hline $10[9]$ & Cinar et al. & 2004 & 7 & M & Painless mass & 10 & Anterior & Transoral & NA \\
\hline $11[8]$ & Nakasato et al. & 2005 & 9 & $\mathrm{~F}$ & Bleeding/ulceration & 20 & Postero-lateral & Transoral & 17 \\
\hline $12[8]$ & Vafiadis et al. & 2005 & 18 & M & Painless mass & 31 & Anterior & Transoral & 36 \\
\hline $13[10]$ & Enoz et al. & 2006 & 7 & M & Dysphagia/pain & 25 & Anterior & Transoral & 60 \\
\hline $14[8]$ & Hsu et al. & 2006 & 9 & M & Painless mass & 12 & Anterior & Transoral & 56 \\
\hline $15[8]$ & Hsu et al. & 2006 & 15 & $\mathrm{~F}$ & Painless mass & 12 & Anterior & Transoral & 136 \\
\hline $16[8]$ & Hsu et al. & 2006 & 12 & $\mathrm{~F}$ & Painless mass & 16 & Anterior & Transoral & 13 \\
\hline $17[8]$ & Pereira et al. & 2008 & 12 & M & Painless mass & 15 & Postero-lateral & Transoral & 12 \\
\hline 18 [8] & Gupta et al. & 2009 & 18 & $\mathrm{~F}$ & Painless mass & 10 & Anterior & Transoral & NA \\
\hline $19[8]$ & Karaca et al. & 2010 & 13 & $\mathrm{~F}$ & Dysphagia & 20 & Postero-lateral & Transoral & 12 \\
\hline $20[8]$ & Naidu et al. & 2010 & 12 & M & Paresthesia/bleed/ulceration & 20 & Antero-lateral & Transoral & 3 \\
\hline $21[11]$ & Husain et al. & 2011 & 10 & $\mathrm{~F}$ & $\begin{array}{l}\text { Difficulty in mastication and } \\
\text { phonation }\end{array}$ & 50 & Antero-lateral & Transoral & 12 \\
\hline $22[8]$ & Lukšić et al. & 2011 & 10 & M & Painless mass & 15 & Postero-lateral & Transoral & 60 \\
\hline $23[11]$ & Manna et al. & 2012 & 15 & M & $\begin{array}{l}\text { Difficulty in mastication/ } \\
\text { swallowing }\end{array}$ & 17 & Posterior & Transoral & 6 \\
\hline $24[11]$ & Bhola et al. & 2014 & 14 & $\mathrm{~F}$ & Painless mass & 15 & Antero-lateral & Transoral & 12 \\
\hline $25[8]$ & Moreno-Garcia et al. & 2014 & 13 & $\mathrm{~F}$ & Painless mass & 20 & Anterior & Transoral & 12 \\
\hline $26[12]$ & Franco et al. & 2017 & 14 & M & NA & 15 & NA & NA & NA \\
\hline $27[13]$ & Fan et al. & 2017 & 16 & M & Painless mass & 25 & Posterior(tongue base) & Transoral & 22 \\
\hline $28[14]^{c}$ & Amer et al. & 2018 & 13 & $\mathrm{~F}$ & $\begin{array}{l}\text { Painless mass with chewing } \\
\text { difficulty }\end{array}$ & 20 & Anterior & Transoral & NA \\
\hline $29[15]$ & Ahmad et al. & 2020 & 14 & $\mathrm{~F}$ & Dysphagia & 30 & Posterior & Transoral & 24 \\
\hline \multirow[t]{5}{*}{30 [16] } & Thompson et al. & 2020 & 12 & $\mathrm{~F}$ & Lingual mass & 7 & Anterior & Transoral & 48 \\
\hline & & & 12 & $\mathrm{~F}$ & Lingual mass & 15 & Anterior & Transoral & 9 \\
\hline & & & 18 & M & Lingual mass & 7 & Anterior & Transoral & 70 \\
\hline & & & 17 & $\mathrm{~F}$ & Lingual mass & 31 & Anterior & Transoral & 14 \\
\hline & & & 17 & M & Lingual mass & 7 & Anterior & Transoral & 1 \\
\hline 31. & Present case & & 13 & $\mathrm{~F}$ & Recurrent painless mass & 20 & Posterior & Transoral & 36 \\
\hline
\end{tabular}

$S N$ serial number, $M$ male, $F$ female, $m m$ millimeter, $N A$ not available, $F U$ follow-up

aLargest dimension of the tumor

${ }^{\mathrm{b}}$ Case of malignant schwannoma)

'The patient with neurofibromatosis-2

transorally. However, in cases with large tumors especially involving the posterior tongue/base of tongue or in cases with restricted mouth opening, an external approach (submandibular, lip split, mandibulotomy, or anterior midline glossotomy approach) may need to be resorted to for adequate surgical exposure. A complete surgical excision leaves no room for recurrence. 


\section{Conclusion}

Schwannomas involving tongue are rare neurogenic tumors, especially in the pediatric age group. A complete excision with sufficient margin leaves no room for recurrence. However, enucleation of the lesion or excisional biopsy in the tongue can result in recurrence of the lesion predisposing the patient to the morbidity of repeat surgical procedure.

\section{Acknowledgements}

None.

\section{Authors' contributions}

Study concept and design: AS, AKK, and VK. Acquisition, analysis, or interpretation of data: AS, AKK, and VK. Drafting of the manuscript: AS and AKK. Critical revision of the manuscript for important intellectual content: AS, AKK, and VK. Administrative, technical, or material support: AS, AKK, and VK. All authors have read and approved the manuscript.

\section{Funding}

This work did not receive any specific grant from funding agencies in the public, commercial, or not-for-profit sectors.

\section{Availability of data and materials}

Not applicable

\section{Declarations}

Ethics approval and consent to participate

Ethics approval is not applicable. Consent to participate was obtained from the parents of the patient.

\section{Consent for publication}

Written and informed consent to publish this information was obtained from the parent of the study participant.

\section{Competing interests}

The authors declare that they have no competing interests.

Received: 11 March 2021 Accepted: 5 April 2021

Published online: 15 April 2021

\section{References}

1. Dreher A, Gutmann R, Grevers G (1997) Extracranial schwannoma of the ENT region. Review of the literature with a case report of benign schwannoma of the base of the tongue. HNO 45(6):468-471

2. Sawhney R, Carron MA, Mathog RH (2008) Tongue base schwannoma: report, review, and unique surgical approach. Am J Otolaryngol 29(2):119122. https://doi.org/10.1016/j.amjoto.2006.08.003

3. Pfeifle R, Baur DA, Paulino A, Helman J (2001) Schwannoma of the tongue: report of 2 cases. J Oral Maxillofac Surg 59(7):802-804. https://doi.org/10.1 053/joms.2001.24298

4. Craig D (1964) Neurilemmoma of the tongue. Arch Dis Child 39(205):297298. https://doi.org/10.1136/adc.39.205.297

5. Uj J (1967) Neurinoma of the tongue. Report of a case. Oral Surg Oral Med Oral Pathol 23:787-788

6. Barbosa J, Hansen LS (1984) Solitary multilobular schwannoma of the oral cavity. J Oral Med 39(4):232-235

7. Piatelli A, Angelone A, Pizzicannella G, Piatelli M (1984) Malignant schwannoma of the tongue. Report of a case and review of the literature. Acta Stomatol Belg 81(3):213-225

8. Lee EY, Kim JJ, Seok H, Lee JY (2017) Schwannoma of the tongue: a case report with review of literature. Maxillofac Plast Reconstr Surg 39(1):17 https://doi.org/10.1186/s40902-017-0116-2

9. Cinar F, Cinar S, Harman G (2004) Schwannoma of the tip of the tongue in a child. Plast Reconstr Surg 114(6):1657-1658

10. Enoz M, Suoglu Y, Ilhan R (2006) Lingual schwannoma. J Cancer Res Ther 2(2):76-78. https://doi.org/10.4103/0973-1482.25856
11. Bhola N, Jadhav A, Borle R, Khemka G, Bhutekar U, Kumar S (2014) Schwannoma of the tongue in a paediatric patient: a case report and 20year review. Case Rep Dent 2014:780762

12. Franco T, de Freitas Filho SA, Muniz LB, de Faria PR, Loyola AM, Cardoso SV (2017) Oral peripheral nerve sheath tumors: a clinicopathological and immunohistochemical study of 32 cases in a Brazilian population. J Clin Exp Dent 9(12):e1459-e1465. https://doi.org/10.4317/jced.54338

13. Fan S, Zhang DM, Chen WL (2017) Endoscopy-assisted resection of benign lesions on the base of the tongue via the transoral approach using a harmonic scalpel. J Oral Maxillofac Surg 75(10):2242-2247. https://doi.org/1 0.1016/j.joms.2017.03.002

14. Amer SM, Ukudeyeva A, Pine HS, Campbell GA, Clement CG (2018) Plexiform schwannoma of the tongue in a pediatric patient with neurofibromatosis type 2: a case report and review of literature. Case Rep Pathol 2018:9814591

15. Ahmed S, Al Dayel O, Tabassum N, Al Quanabr MH, Ali HA, Mathekor N et al (2020) Lingual schwannoma in an adolescent girl- a diagnostic challenge. J Family Med Prim Care 9(3):1775-1777. https://doi.org/10.4103/jfmpc. jfmpc_1142_19

16. Thompson LDR, Koh SS, Lau SK (2020) Tongue schwannoma: a clinicopathologic study of 19 cases. Head Neck Pathol 14(3):571-576. https://doi.org/10.1007/s12105-019-01071-9

\section{Publisher's Note}

Springer Nature remains neutral with regard to jurisdictional claims in published maps and institutional affiliations.

\section{Submit your manuscript to a SpringerOpen ${ }^{\circ}$ journal and benefit from:}

- Convenient online submission

- Rigorous peer review

- Open access: articles freely available online

High visibility within the field

- Retaining the copyright to your article

Submit your next manuscript at $\boldsymbol{\nabla}$ springeropen.com 